\title{
The Influence of Study-Abroad Experiences on Chinese College EFL Teacher's Identity
}

\author{
Yan Zhao \\ The University of Alabama \\ Miguel Mantero \\ The University of Alabama \\ e-mail:mmantero@ua.edu
}

\begin{abstract}
:
The purpose of this study was to explore how in-service Chinese college English teachers produce and reproduce their identities within their study-abroad experiences in terms of their beliefs and classroom practice. Sociocultural theory, discourse theory, and activity theory were used in the theoretical framework to analyze how participants modified their self-perception and changed their classroom practice in different contexts during boundary crossing. The study invited four in-service Chinese college English teachers who took part in three-month study-abroad program. Data were collected from interviews, observations, and document analysis. The findings indicated that participants shifted their selfperception from advanced language user to basic language learner when they studied abroad and had difficulty in dealing with daily tasks. With deeper involvement in the U.S. American culture, they gained more confidence in teaching. After they returned, they were more creative and critical teachers. The findings also demonstrated that participants wanted to implement the latest pedagogies, activities, and management into their own classrooms based on their students' needs and levels in the Chinese sociocultural context. Although participants encountered challenges in implementation due to students' levels, learning habits, and local context, they made some effective changes and formed new authority in the
\end{abstract}


classroom. This study suggests that in order to improve study-abroad programs into truly beneficial professional development for teachers, college teachers need to have a clear self-evaluation process, and institutional administrators and foreign directors of study-abroad programs need to stand in teachers' shoes to meet their requirements. This, in turn, will bring more Chinese college English teachers to study abroad for professional development.

Keywords: study-abroad experiences, EFL, teacher's identity

\section{Introduction}

China has a long tradition of respecting teachers. A teacher is defined as one who could propagate doctrine, impart professional knowledge, and resolve doubts. The role of the teacher has significant prominence in Chinese society. In the era of fastdeveloped economy and technology, the role of teachers, as the introducers of knowledge, is more widely and deeply recognized by the public. In the $21^{\text {st }}$ century, the Chinese Ministry of Education (1993) highly valued the significance of teachers in that education is the way to revitalize a nation. Therefore, teachers' qualifications and teachers' continued training has attracted more and more attention not only from the government but also from teachers themselves. In addition, under the influence of globalization and internationalization of education, study-abroad programs have become a popular form for teachers' professional development programs.

For instance, since 2002, hundreds of teachers in higher education, fully sponsored by the China Scholarship Council (CSC), are sent to English-speaking countries (e.g., the U.S., Britain, and Australia) and enrolled in all kinds of study-abroad programs every year (Ministry of Education, 2004; Ministry of Education, 2011). These study-abroad programs differ in length from three months to a year, but they have similar objectives; including improving teachers' capability of bilingual teaching making teachers more competitive, increasing opportunities for international cooperation, and accelerating higher education reform (Ministry of Education, 2004). There are also study-abroad programs specifically for English teachers in higher education, such as a ten-month Singapore Nanyang Technological University English Teachers' Training Program and a six-month study-abroad program at the University of Aberdeen in Britain (Ministry of Education, 2007; Ministry of Education, 2011). English teachers in higher education from remote and less developed areas in China are privileged to take part in these two programs.

The training syllabus in these programs focuses on the enhancement of linguistic skills and cultural knowledge, on theories and methodologies of English teaching, and on academic writing. The objectives include the following: 1) cultivating teachers with high language proficiency; 2) improving English teachers' research skills; 3) preparing for English teaching reform of higher education in western regions of China; and 4) meeting the need of economic and social development in western regions of China (Ministry of Education, 2007). In addition to these studyabroad programs introduced and sponsored by the central government, a larger 
proportion of various study-abroad programs are advocated by provincial governments, local colleges, universities, and teachers themselves.

In order to encourage more teachers to participate in the study-abroad programs to develop professionally, and to improve education quality, many policies on teachers' promotions with regard to professional development are enacted. Many universities and colleges issue regulations to explicitly state their principles of teacher promotion. For instance, both Zhejiang University and Shanghai University of Finance and Economics require that teachers must have at least a six-month overseas study or research experience in order to be promoted (International Office of Shandong University of Finance and Economics, 2013). Universities and colleges also provide priority or potential benefits to teachers with study-abroad experience. For instance, the Foreign Language Examination for National Professional and Technical Personnel can be waived for teachers with at least one-year of overseas study experience during their promotion process (The Central People's Government, 2007). In conclusion, these mandatory regulations, explicit priority, and potential benefits encourage teachers in higher education to seek study abroad opportunities, which reveals the necessity of this research on the impact of study-abroad experience on in-service Chinese university English teachers' identity formation and negotiation.

\subsection{Statement of Problem}

Because of the wide recognition of its significance and effectiveness for teacher education, international experiences have been studied from different perspectives; including global education, education reform, and teacher's identity, among which, studies from the perspective of global education account for a large proportion (Lee, 2009). The effectiveness of overseas experience for teachers can account for increased self-efficacy, increased cultural knowledge, and a broad global perspective. Merrell (2003) argued that in order to develop cultural awareness and understand others, people must "get it", which is interpreted as "re-assessing our identities, re-visiting our needs, and most of all, re-inventing ourselves". This interpretation echoes Yazan's (2014) argument that teacher education programs prepare teacher candidates not only in their pedagogical knowledge and skills but also in their teacher identity construction. In brief, overseas experience, as a component of a teacher's study-abroad education program, is pivotal to teachers' identity construction and development.

The purpose of this study was to explore in-service Chinese university English teachers' study-abroad experiences. Second, this study aimed to further understand the impact of teachers' study-abroad experiences on their language proficiency and cultural understanding. Finally, this study investigated what teachers implement in their own classrooms. The following research questions were posed in order to understand how study-abroad experiences impact the Chinese university English teachers' identity:

1) In what ways do study-abroad experiences influence Chinese university English teachers' understandings and teachings of American culture? 
2) In what ways do study-abroad experiences impact Chinese university English teachers' pedagogical practices?

\section{Theoretical Assumptions}

\subsection{Definitions of Identity}

Identity has become one of the most frequently employed concepts in the social sciences and humanities in the fields of education and applied linguistics (Morgan \& Clarke, 2011). Due to its popularity, there are many competing frameworks and discourses around the notion of identity, such as situated learning/community of practice (Varghese, 2000; Yazan, 2014), sociocultural theory (Reis, 2011), poststructuralism (Ajayi, 2011; Golombek \& Jordan, 2005; Mantero, 2004; Morgan, 2004), language socialization (Duff \& Uchida, 1997), symbolic interactionism (Martel, 2015), social identity theory (Johnson, 2001) and so forth. Although these studies investigate identity from different perspectives, they generally view identity as a constantly developing sociocultural construct (Martel \& Wang, 2015). These various theoretical frameworks also encompass a community of practices, experiences, power, agency, and discourse into identity formation and development. They indicate that the general move has been away from identity in terms of psychological processes towards contextualized social processes. The multiple theoretical frameworks on identity confirm Varghese et al.'s (2005) argument that "multiple theoretical approaches allow a richer and more useful understanding of the processes and contexts of teacher identity" (p. 21). The multiple theoretical frameworks on identity also indicate that identity is a complex and evolving process, which requires joint effort and close attention for better understanding.

While identity in general has been a hot research topic, teacher identity in bilingual and second language education has only recently emerged as a subtopic within the fields of language teacher education (Varghese, 2001). Although language teacher identity typically draws the attention of researchers for a short period, it is considered a crucial construct to conceptualize both teacher learning and language teacher education (Martel \& Wang, 2015). Teacher identity plays a key role in every aspect of the teacher profession. For instance, teacher identity 1) creates a model for teachers as the kind of teacher they want to be; 2) affects their roles in classrooms, the content they teach, their instructional management; and 3) influences their relations with students, colleagues, students, parents, and so forth (Beijaard, Meijer, \& Verloop, 2004).

Teacher identity, as one type of identity, has been variously defined. Many scholars pointed out that on the one hand, the vagueness of concepts related to teacher identity would lead to ambiguity and misunderstanding, but on the other hand, the richness and depth of these concepts also invited further exploration.

Definitions of language teacher identity under guidance of different approaches stresses different roles of social interactions, group membership, context, power, agency, discourse, race, and gender in teacher identity formation and development. Although they have different emphases on teacher identity, several similarities can be drawn from them: 
- language teacher identity is comprised of language teachers' selfperception, beliefs, and ideas (Johnson, 2001; Martel, 2015);

- language teacher identity is dynamic and evolving (Martel, 2015; Motha, 2006; Reis, 2011);

- language teacher identity construction largely depends on institutional, social, cultural, and political contexts (Morgan, 2004);

- language teacher identity is multi-dimensioned rather than single-layered (Johnson, 2001; Motha, 2006; Reis, 2011);

- language teacher identity construction requires taking consideration of power and discourse (Morgan, 2004; Reis, 2011).

It is noteworthy that these similarities to some extent resonate with Beijaard et al.'s (2004) findings of features of professional identity. Besides this, it is also noted that the conceptualization of language teacher identity highlights power relations in identity formation and development. Moreover, language teacher identity is both a process and a product. For instance, Morgan's (2004) perception of language teacher identity as pedagogy is a starting point of pedagogical application of teacher identity. In other words, language teacher identity can become a classroom resource or a text to be performed.

\subsection{Optional Definition of Teacher Identity Construction}

Teacher identity has been studied with the relation to becoming a teacher. For instance, Danielewicz (2001) addressed that being a teacher required not only methodological or ideological equipment but also engagement of identity. In addition, becoming a teacher is a process of bringing personal beliefs and experiences related to teaching and taking new and complex ideas in new contexts (Britzman, 2003; Darling-Hammond, 2000). In terms of teacher identity production, transformation is critical to understand teacher identity production and reproduction. Britzman (2003) described "learning to teach" as "the process of becoming: a time of formation and transformation, of scrutiny into what one is doing, and who one can become" (p. 31). His description revealed the dynamic nature of identity construction and transformation, which echoed Akkerman and Meijer's (2011) conceptualization of teacher identity as dynamically evolving.

Teacher identity construction is a circular and forward-moving process rather than a journey with discrete and linear parts. Teachers constantly bring the past, present, and future together to reflect and predict professional beliefs, goals, and memories while enacting practice. Recognition and reflection of teacher identity should be for all teachers, both pre-service and in-service, who teach at elementary, secondary, and post-secondary schools. Teacher identity formation, which is associated with being a teacher, takes its significance throughout the teaching profession.

\subsection{Impacts of Study-abroad Experience on Language Teachers}

Compared to the large percentage of majors in social sciences $(21 \%)$, business and management (19\%), and humanities (13\%), foreign language majors only account for a small percentage $(7.2 \%)$ of study-abroad participants in the U.S. (Allen, W., 
2010; Institute of International Education, 2008 \& 2015). Therefore, the number of existing research studies concerning the influence of study-abroad experiences on foreign language teachers, especially on foreign language teacher identity, is limited. Studies on U.S. foreign language students and teachers account for a significant number of these studies. The objectives of study-abroad programs for teachers, in general, are cultivating global perspectives and enhancing cultural awareness; however, achieving high language proficiency and better cultural understanding are the predominant two objectives of study-abroad programs for foreign language teachers (Allen, Q., 2010; Thompson, 2002).

Although study-abroad programs for foreign language teachers similarly stress language proficiency and cultural understanding, the influence of study-abroad experience on foreign language teachers is controversial. It is negatively stated that study-abroad participants reposition themselves as a language learner and lose the sense of being a language teacher because they have fewer opportunities to exercise their agency within the classroom during study-abroad (Lavender, 2002). With the view of language enhancement as pivotal to their professional confidence, the studyabroad participants have high expectations for language proficiency improvement and take activities to practice and learn in different contexts both inside and outside of classrooms. However, the study-abroad programs only focus on a teacher's academic and professional qualification rather than their own expectations and live experiences outside of the classroom. On the contrary, the positive influence of study-abroad on foreign language identity is also examined and confirmed by a cohort of studies (Thompson, 2002). For instance, Thompson's study (2002) found that most of his participants had significant gains in their linguistic abilities in terms of reading, vocabulary, and grammar; improved their cultural knowledge of Spain; and had a positive attitude towards the Spanish culture. These positive gains are usually connected with the potential for professional development. Therefore, study-abroad participants prove to students, parents, and the community that they can meet their needs and expectations and view themselves as more qualified teachers with increased linguistic, cultural, and pedagogical abilities.

The aforementioned studies focus on the influence of study-abroad experience on U.S. foreign language teacher identity during their study abroad or immediately after they return to their native countries. Barnawi and Le Ha (2015) conducted a case study of two Saudi EFL teachers to examine their study-abroad experiences on their teacher identity when they taught in their home contexts. The findings revealed that the study-abroad experiences empowered participants within their home context and this empowerment brought various types of privilege. Those study-abroad participants made use of what they learned in the West to teach effectively with awareness and a strong sense of agency and their authority in classroom had never been challenged. In addition, they were viewed as more qualified than other colleagues with locally educational backgrounds and their autonomy, beliefs, and experiences were more recognized. Barnawi and Le Ha's (2015) study confirmed Thompson's (2002) findings that the study-abroad experience had positive 
influences on foreign language teacher identity in terms of establishing their confidence, authority, and agency.

In brief, the existing research underscores the influence of study-abroad experience on U.S. foreign language teachers in other countries (such as Spain, France, and Mexico) rather than on influence of study-abroad experience in English speaking countries on EFL teachers from non-English speaking countries. In the next section, I introduce effects of study-abroad experience on Chinese EFL teachers.

\subsection{Effects of Study-abroad Experience on Chinese Language Teachers}

In the last two decades, the Chinese government selected and sent thousands of EFL teachers to English-speaking countries for their professional development. Chinese EFL teachers' study-abroad experiences attracted scholars' attention and raised their interest to explore the influence of Chinese EFL teachers' study-abroad experience on their identity.

The studies discovered that teachers' perceptions mainly changed in the following categories: language proficiency (Barhuizen \& Feryok, 2006; Gleeson \& Tait, 2012; Lee, 2009; Trent, 2011; Wang, 2014), teaching ideology (Wang, 2014), cultural awareness (Barhuizen \& Feryok, 2006; Gleeson \& Tait, 2012; Lee, 2009; Trent, 2011), Non-native English-speaking teachers-Native English speaking teachers (NNEST-NEST) dichotomy (Wang, 2014), personal growth (Barhuizen \& Feryok, 2006; Lee, 2009), and pedagogical understanding (Barhuizen \& Feryok, 2006; Lee, 2009), all of which can be connected with teachers' identity transformation.

In terms of linguistic identity, EFL teachers have to change from language teacher in China to language learner/user in a target culture (Gleeson \& Tait, 2012; Wang, 2014). The key for identity change is language proficiency. Lee (2009) showed that target language proficiency played an important role in NNESTs' self-esteem and sense of security. That is why almost all study-abroad programs set improvement of language proficiency as one of their goals or expectations. Chinese EFL teachers with study-abroad experience admitted that the programs provided language learning environments for them to develop their language (Barhuizen \& Feryok, 2006; Gleeson \& Tait, 2012; Lee, 2009). Length of stay also contributed to language proficiency. The longer the study-abroad program, the more confident and reassured Chinese EFL teachers felt to be competent English users (Wang, 2014).

In term of professional identity, perceptions of teaching ideology and NESTNNEST dichotomy are essential. Traditionally, Chinese EFL teachers believed that British English was the standard language for classroom instruction (Wang, 2014). They considered English as a Native Language. With this perception, they thought NEST are ideal models for English teaching. With these perceptions of English and NEST-NNEST dichotomy, Chinese EFL teachers felt that they were less qualified. During study-abroad programs, perceptions changed into English as an International Language and favor of NNEST majority. In other words, English varieties were acceptable (Lee, 2009; Wang, 2014) and NNESTs were also viewed as good language teachers. As a result, Chinese EFL teachers gained authority over language. 
In terms of sociocultural identity, overseas experiences, especially social activities and homestay experiences, were mainly attributed to perceptions of culture. Chinese EFL teachers reported that they began to reflect on their own culture and their way of life and had a sense of multiculturalism (Barhuizen \& Feryok, 2006; Gleeson \& Tait, 2012). They also had a better understanding of the target culture (Barhuizen \& Feryok, 2006; Lee, 2009). They learned to accept and appreciate cultural differences. In other words, study-abroad experiences encouraged the growth of intercultural awareness (Jackson, 2006). Chinese EFL teachers developed certain attitudes towards cross-cultural differences and insights about their own cultural identities.

In conclusion, studies examining the influence of study-abroad programs on Chinese EFL teachers' identity construction are still scarce. The limited existing research was majorly composed of studies exploring study-abroad experience of Chinese EFL teachers from Hong Kong. The paucity of studies of study-abroad experience of Chinese EFL teachers from Mainland China attracted my attention. In addition, most research was conducted by foreign administrators or mentor teachers from an outsider perspective with Western epistemology and ontology rather than from an insider perspective of Chinese EFL teachers themselves. All of these served as a guideline for my research in order to fill the research gap from a Chinese perspective. In the next section, I introduce what I want to do based on the findings of these existing studies.

\section{Research Design}

Since the current study aimed to explore the perceptions, experiences, and identity negotiation of Chinese college EFL teachers who had studied abroad within natural settings, a qualitative inquiry was adopted. Through choosing a case study perspective, the researcher investigated Chinese college EFL teachers' understandings of American culture and their pedagogical practices in their own classrooms after their sojourns. Guided by sociocultural theory and activity theory of identity, each case revealed Chinese college EFL teachers' stories of their professional development within their respective contexts. With the aim to achieve triangulation, data for the case study were collected from interviews, classroom observations, and teaching documents. These data sources helped the researcher to better understand the study-abroad experiences of Chinese college EFL teachers and their professional identity construction from multiple lenses.

\subsection{Research Sites}

\subsubsection{The Home University}

Jiangnan University (pseudonym) is located in the southeastern coastal area of China next to Shanghai, which is the most economically and culturally developed city in China. The city where the university is located is famous for its Jiangnan culture prevailing in the south of the Yangtze River and for its cultivated scholars throughout the history. The city has developed rapidly; at the end of the year 2015, the population reached to almost 3.5 million, and the gross domestic product was over 351 billion Chinese Yuan. 
Jiangnan University, which was established in 1914, is the most famous higher education institute in the city. It is a public comprehensive university with varied academic programs covering business, management, arts and science, medicines, and etc. According to the statistics of enrollment for the 2015-2016 academic year, the number of full-time students was around 15,000 and the number of faculty and staff was over 1,700. Since its establishment, Jiangnan University has been responsible for cultivating high-quality citizens. Due to its location and convenient transportation, as well as a growing economy, Jiangnan University has more opportunities to collaborate with over twenty overseas universities in the United States, Great Britain, Denmark, Germany, Japan, and Korea. Within the University, the Foreign Affair Office and Institute of International Education is responsible for seeking opportunity to establish good relationships with overseas colleges and universities to exchange students and visiting scholars. The College of Foreign Studies is composed of the Department of Japanese, Department of College English, and Department of Intensive English. The Department of Intensive English is responsible for teaching English majors who will be English teachers, translators of written texts, or simultaneous interpreters after graduation. Therefore, the first twoyears of teaching underscore pronunciation, listening, reading, writing, speaking, and grammar. The last two-years of teaching focus on teaching pedagogy, teaching assessment, British and American literatures, and business English. The above mentioned institution and college are attributed with the success of study-abroad programs. All participants are from the Department of Intensive English.

\subsubsection{The Host Universities}

The first host university is a public university with a long history in the southeast of the United States. As the state's flagship university, it ranks among the Top 50 public universities by U.S. News and World Report. In the 2015-2016 academic year, the student population was 37,665, with diverse educational, cultural, and social backgrounds. The Office of International Program (OIP) within the College of Education was established in 1966. Since its beginning, the office was dedicated to provide students with opportunities to study abroad in order to become qualified educators. The Office also ran programs for overseas teachers who had the need of professional development and graduate degree. The programs included sending teachers periodically to overseas campuses to teach and short-term programs that trained teachers from other countries.

The study-abroad program was conducted in the above mentioned university for the first three years (from 2010 to 2012). Then the program in 2013 and 2014 moved to a second host university as the Director of OIP found a job there. The second host university, which was located in the northeast of the U.S., also had a long history since its establishment in 1871. From the beginning, it primarily aimed to train teachers to serve the fast-growing student populations in local public schools. Now, as a public university, the second host university is dedicated to teaching, research, service, scholarship, creative activities, and cultural enrichment. In the 2014-2015 academic year, the number of registered students in the second host university was 11,083 and more than 1,200 employees worked to facilitate students' success. 


\subsection{Participants}

Case selection is critical to better understand the phenomenon (Yin, 2009). A successful case selection indicates that the selected cases should represent the larger group of interest (Stake, 2005). Stake (2005) pointed out that, for qualitative fieldwork, a purposive sample is needed to "build in variety and acknowledge opportunities for intensive study" (p. 451). Purposive sample, or selecting "information-rich cases," ensures that researchers can get in-depth data.

From 2010-2014, five groups of Chinese college EFL teachers (41 teachers in total with 17 females and 14 males) from Jiangnan University took part in the studyabroad program in the host universities. Among these 41 teachers, one teacher retired shortly after the study-abroad program, and another three teachers left the Jiangnan University to pursue higher degree abroad after their participation in studyabroad programs. The remaining 37 teachers were from different departments of Jiangnan University: 14 of them were from Department of Intensive English, College of Foreign Studies; 17 of them from Department of College English, College of Foreign Studies; and 6 of them from College of Education. I invited 14 teachers from the Department of Intensive English based on convenience sampling. First, I built rapport with these 14 teachers when I worked at Jiangnan University. We worked in the same office, discussed curriculum design, and attended regular faculty meeting every other Thursday afternoon. Second, their teaching schedules met my timeframe. In other words, they taught different classes in different days, which meant that their schedules did not overlap.

Before getting access to those teachers with study-abroad experiences, I first contacted the Dean of Colleges of Foreign Studies for her approval to conduct this research. With her permission, I began to contact teachers to get their permission and explain my research goal and procedures. In addition, I promised that all collected data would be safe and locked in my own office and would only used by me for research. Furthermore, I assured them that their teaching routine would not be changed during my data collection process. After introduction of my research and several rounds of questions and answers, four teachers agreed to participate in the current study. Table 1 is a description of participants.

Table 1: Description of Participants

\begin{tabular}{|c|c|c|c|c|c|}
\hline $\begin{array}{c}\text { Name } \\
\text { (pseudonym) }\end{array}$ & Gender & $\begin{array}{c}\text { Year of Study- } \\
\text { Abroad }\end{array}$ & $\begin{array}{c}\text { Year of Teaching } \\
\text { Experience }\end{array}$ & Title & $\begin{array}{c}\text { Courses They } \\
\text { Teach }\end{array}$ \\
\hline Lily & female & 2012 & 6 & $\begin{array}{l}\text { Assistant } \\
\text { Professor }\end{array}$ & Interpretation \\
\hline Haifeng & female & 2011 & 27 & $\begin{array}{l}\text { Associate } \\
\text { Professor }\end{array}$ & $\begin{array}{c}\text { Advanced } \\
\text { English }\end{array}$ \\
\hline Jack & male & 2013 & 7 & $\begin{array}{l}\text { Assistant } \\
\text { Professor }\end{array}$ & $\begin{array}{l}\text { Integrated } \\
\text { English }\end{array}$ \\
\hline Laura & female & 2008,2013 & 27 & $\begin{array}{l}\text { Associate } \\
\text { Professor }\end{array}$ & $\begin{array}{c}\text { Advanced } \\
\text { English }\end{array}$ \\
\hline
\end{tabular}

Lily got her Master's degree in interpretation from a southeastern university in China. Her university performed a leading role in both teaching, researching, and 
testing among colleges and universities of foreign languages in China. Her university also set standards for several important tests for Chinese English learners such as Test for English Majors Band 4 (TEM-4), Test for English Majors Band 8 (TEM-8), and Test for Shanghai Interpretation Accreditation. Lily was very diligent graduate student. She passed TEM-8, College Germany Test Band 6, and Test for Shanghai Interpretation Accreditation (Advanced Interpretation). In her spare time, she also interpreted at many international conferences. After graduation, she worked as a translator for two years and began to work in Jiangnan University in the studyabroad program in China since 2011. In Jiangnan University, Lily mainly taught interpretation to junior students majoring in interpretation for three semesters. She also worked as coordinator with foreign teachers in Jiangnan University. On weekends, she taught Cambridge Young Learners English (CYLE) and Cambridge Business English (BEC). She took part in the study-abroad program in 2012.

Laura was the Dean of the English Department in the College of Foreign Studies. She got her Bachelor's degree in English Education. She has worked in Jiangnan University since 2003. Laura actively tried to teach different courses such as pragmatics, testing, advanced English, etc. In the semester that the study took place, she taught advanced English to junior students (majoring in secondary education). She participated in the study-abroad program in 2013. This was not her first time to go abroad. In 2008, she was elected with other seven colleagues from other colleges and was sent to a Midwest state in the U.S. to have a three-week cultural experience; however, that experience was vastly different from the one in 2013. The former one was composed of one-week stay in a local school and two weeks of travel. It was only a quick glance and Laura gained a superficial understanding of what she saw. The latter trip abroad was a three-week intensive learning experience in school.

Jack graduated with a master's degree in Applied Linguistics from one of top three normal universities in China. During school, he was also the president of the Graduate Student Council in the School of Foreign Languages. Because of his excellent academic achievement and social service, he was recognized as the best graduate in his former university in 2011. In the last year of his graduate study, he began his internship in Jiangnan University and he became a full-time teacher in 2011. He taught the integrative course (basic level) to freshmen and sophomores (four semesters in total). Jack was confident and his confidence came from a profound knowledge and sharp language skills. His teaching was passionate. In addition, Jack set a high bar for his teaching. He spent all day long in his office preparing the lessons and kept improving. He took part in the study-abroad program in 2013.

Haifeng earned her Bachelor's degree in English Language and Literature, and she began to teach in 1990. After nine years of teaching, Haifeng felt the necessity of getting a higher degree, so she returned to school and get her Master's degree in Foreign Linguistics and Applied Linguistics in 2001 from a university in central south of China. A Master's degree for people at her age was uncommon. Haifeng was employed by Jiangnan University in 2005. In Jiangnan University, she taught students at different levels with various courses such as business interpretation, 
international communication, and advanced English. Among these courses, advanced English was the one she taught the longest and the one she favored. In the semester that the study took place, Haifeng taught Advanced English (Book 1) to junior students (majoring in business). She took part in the study-abroad program in 2011.

Although there were only four participants in this study, they generally represented the whole population of the College of Foreign Studies in Jiangnan University with regard to gender, title, teaching experience, and the courses they taught in the semester this study took place.

\subsection{Data Collection and Analyses}

A hallmark of case study research is using a variety of data sources. The exploration of multiple data sources enhances data credibility (Patton, 2002; Yin, 2009). In the current study, data were collected by interviews, observations, and documents. During the data collection, the Dean of College of Foreign Studies was not present.

Summary of the Data Collection Methods

\begin{tabular}{ll}
\hline $\begin{array}{l}\text { Data Collection } \\
\text { Methods }\end{array}$ & Notes \\
\hline Pre-Study Meeting & $\begin{array}{l}\text { To meet the participants, go through and distribute consent form, } \\
\text { and schedule interviews and classroom observations }\end{array}$ \\
Interviews & $\begin{array}{l}60-90 \text { minute session for each participant } \\
\text { To observe participants' instructional management, pedagogy, } \\
\text { and activities (100 minutes session for each participant) } \\
\text { To get complementary information to interviews and } \\
\text { observations }\end{array}$ \\
\hline
\end{tabular}

\section{RESULTS}

The study-abroad program triggered tremendous and far-reaching impacts on participants' pedagogical practice in their own classroom in terms of epistemology, importance of culture in foreign language teaching, classroom activity, classroom management, assessment, and teacher-student interaction.

\subsection{What They Learn}

Epistemology. Participants believed in that culture belonged to a group of people and covered every aspect of their life including tradition, customs, history, life style, and way of thinking, and things like that. Their understanding of culture indicated the nature of culture which was exclusive, comparatively fixed, and typical for specific people. In other words, their epistemology revealed that there was only one correct understanding of culture. However, the question, what American culture looked like, emerged. The United States is a nation composed of immigrants all over the world with over 200 years history. Whose culture, I mean which group of people's culture, can be considered as typical American culture. With the positivist epistemology which believed in that there was only one truth, these participants heavily relied upon knowledge of American culture from books, which they thought 
were authentic. The problem was that some description and interpretations of American culture in different books were different from or even contradictory with each other. In addition, participants' own experience of interaction with Americans was also not in accordance with knowledge in books. This kind of deviation made participants confused. Study-abroad program provided these participants opportunities to immerse in current American culture to experience by themselves. Laura observed actual eating manner of some Americans that were totally opposite to textbook introduction. Similarly, Haifeng noticed different attitudes towards religion between southerners and northerners within the U.S.. Their live experiences taught them poststructualism epistemology that truth can be multiple. In the same vein, American cultures can be diversified. Their understanding of culture also developed in terms of importance of culture in foreign language learning. Lily reminded her embarrassed order experience. She used half foot rather than six inches that was more idiomatic in daily life. Lily's uncommon choice of word did not reside in her lack of linguistic knowledge of English words but in insufficient pragmatic knowledge. Due to different measuring parameters in the U.S. and China, she had difficulty in converting between foot and inch but also in use the appropriate word according to context. Her embarrassment illustrated sociolinguistic competence in communication. In brief, after study-abroad, these participants gained profound understanding of culture.

Classroom activity. Laura stated that she learned how to guide students to conduct task-based project from study abroad.

有一节课是两个老师一起来做lecture的，那么他们两个当时介绍了他们 两个正在进行的教学模式，有点像project，就是这种项目式的，那么对 于当地的...像是让学生去做环境方面的调查，然后老师给予一定的指导 , 学生回来比如说写一个report,

做presentation哪，那他的这种教学方式我当时感到非常的新颖。首先我 们在国内这方面是搞得比较少的，尤其是我们是语言教师，就感觉好像 做这个project不知道怎么去做，然后这个没有任何的idea当时，就是这 样的一种感受。

\section{(Translation)}

When we studied abroad, one day two teachers introduced their teaching model, something like a project. They asked their students to investigate local environmental issues and guided their students to write a report or to do a presentation. Their teaching method was very novel to me, because teachers in China seldom guided students to do projects in class. Especially language teachers like us, we had no idea about how to conduct a project in class. 
Laura was inspired by foreign teachers and had insight into how to conduct projects. She began to consciously design close to life tasks for students. In my first observation of Laura's class, I notice she required students to compile tourist pamphlet of their hometown, to interview teachers with abroad experiences, to write book report of Macbeth, and to reflect on novel reading. These projects were tight related to the textbook and also close to students' daily life. The most important thing is that these classroom activities are communicative.

Another technique participants learned is how to create an authentic environment for students to practice the target language. All participants valued the importance of authentic environment for language learners to grasp the foreign language. However, in China, as the non-English-speaking country, it was difficult to create an authentic environment for students. In her interview, Laura described a lesson about how she observed an American teacher who created a real context for students to learn how to go shopping.

就是说比如说教给学生go

shopping去购物, 然后这个老师, 当时我们很惊讶的是, 他带了一个特

别大的箱子来, 然后他就在我们上课的教室里面布置出一个像小市场一 样的，他就是在衣架上挂了很多衣服，在桌子上摆了很多首饰，鞋子啊 各种商品, 然后让我们来担当不同的角色, 比如说有的当 saleswoman, 有的就是做顾客，整个这个过程当中他用这个方法首先它是一种模拟， 就是模拟真实的场景。

\section{(Translation)}

We observed a class of how to teach go shopping. To our surprise, the teacher brought a large suitcase full of merchandises. He decorated the classroom into a supermarket. Lines of clothing rack were full of clothes, shoes and jewelries were placed on the desks. Then the teacher asked us to play different roles such as saleswoman and customers. During the whole period, he created a real shopping environment.

Compare with glossing over the context as her previous way of teaching, Laura was deeply impressed by the foreign teacher's effort and intention to design in order to help student have a real sense of shopping. After that, Laura also designed some real situation in her classroom to help students experience typical American life. For instance, she bought some forks and knives and asked student how to place them and how to use them in order to learn American table manner.

Classroom management. Some participants admitted that their students did their own work without cooperation with classmates. After study-abroad, these participants learned how to group students and how to encourage them to collaborate in order to scaffold their own learning. The following paragraphs revealed Lily's understanding of peer work. 
他们的写作就是他们自己相互之间改，起先我们觉得这种方式不是特别 好，就是觉得学生能改出东西吗? 但是他们经过几轮修改后我们看到的 那些poems真的是非常棒的。所以说我觉得学生跟学生之间的一个思维 的碰撞也是非常非常好的。

\section{(Translation)}

American students exchanged their writing assignments in class and scored each other's papers. At first, we were doubtful about whether students can learn from peer assessment. Later we found that their peer revised poems were excellent. After that I believed that communication and cooperation between students was effective for learning.

Lily's attitude towards peer work changed from negative to positive when she saw its effectiveness in students' academic achievement. She thought students could learn something from their classmates through scoring. Lily indeed integrated peer work into her classroom. During my observation, in her class, Lily required students' cross correction of dictation and translation exercises. She believed in that cross correction was also a learning process for students and also a push to study harder when students saw classmates' performance and realized the gap.

Jacks listed how to effectively interact with students as one of his biggest studyabroad achievement.

We learned some western advanced teaching ways or teaching ideas, such as to give students more time to think and to present themselves, which is different from our Chinese class, because we have so many students, it is usually noisy in the classroom, that's why for most of time the teacher should control to organize the class atmosphere, but in America I saw students will express their ideas very freely and they can interrupt teacher at any time they want.

Jack's interview revealed the truth that the size of language learning classrooms (3060 students) in China were too big. On one hand, the length of class was fixed (45 minutes). On the other hand, teachers had to complete teaching tasks aiming at 30 students within 45 minutes. It was not difficult to image that student had less chance to speak out. Jack made efforts to make changes in his own classroom to give students more time to think about, to discuss with their partners, and to express themselves.

Another teaching technique Jack learned from study-abroad was giving more attention to students' response during teaching.

I think in America, the teacher will observe students in the class, this kind of observation will be very useful for the growth or the development for specific student, that's why when I back to China I will consciously observe some of students I think most of them are not very good at English learning, 
Zhao \& Mantero, The Influence of Study-Abroad Experiences on Chinese College EFL

so after observation I will give some suggestions and ideas how to study and how to learn better.

Jack learned to pay more attention to students; especially those who had difficulty in learning. My observation of Jack's class confirmed his words. Jack asked students in turns to share a Chinese idiom story with their classmates. He facilitated students to better prepare their presentation including grammar, pronunciation, and translation. After each session, he would talk with students for feedback. Jack discovered that his suggestions were functional and beneficial to students.

Various ways to evaluate. Almost all participants pointed out that they learned how to use different ways to evaluate students throughout the whole semester rather than their previous focus on final written test. For instance, Lily showed her interest in portfolio assessment.

他这个考核方式我觉得就是有一种特别好的理念，他不是说你分数高你 分数低，他是说每个人都把这一阶段学习，用比较creative way的方式展现出来, 我觉得这个特别好。尤其是他们进来, 你就像一 个展柜一样，把自己的成果告诉人家，就觉得很proud. 这个portfolio很好...我觉得这种考核方式很好，尤其是相对那些比较灵 活自由的课，不需要一定说我一定要比个高低。其实你比个高低那个方 法也不一定科学, 反而打击学生自信心。

\section{(Translation)}

I think the philosophy of portfolio assessment is good. Their purpose is not to show who is better but to show one's learning progress in a creative way. Just like when we presents our post to others to tell them what we have achieved in 3-month study in the U.S., we are very proud of our progress...I think portfolio assessment is a good way for those relatively flexible courses to evaluate students. The purpose of traditional evaluation is to rank students. Actually it is not scientific, and it also destroys students' confidence in learning.

In Lily's opinion, in some elective courses, portfolio assessment was better than the traditional way of ranking students according to their scores in final tests. She realized students' diversity in study pace and study habit, so she placed focus on students' own progress and what they acquired gradually through the whole semester. She no longer compared students with others only by scores. Besides portofolio assessment, Laura and Jack implemented formative assessment to underscore students' progress.

In sum, participants to different extent benefited from their study-abroad experience. Just like sponges, they quickly absorbed knowledge, teaching pedagogies, classroom activities within short period. They were curious about some concrete classroom activities, such as walking dictation, jigsaw, and book club. They were refreshed by 
updated project-based and communicative teaching methods. They were also enlightened by a teaching philosophy that students were the core of language classes. After they came back, they integrated what they learned into their own classroom with great expectation of students' huge academic achievement. However, they came across lots of obstacles. Some of them were attributed to students' stereotype of grammar-translation teaching method, students' uneven English levels, and heavy workload and pressure. Others were due to administrative restriction on teachers' teaching, oversized classroom, and Chinese educational system. To take these social, cultural, and political factors into consideration, all participants pointed out they did not blindly accept and integrate but localized implement what they learned from study-abroad program.

\subsection{Ways to Implement}

Contextualization. Lily appreciated a large proportion of discussion between students in American classroom. She stated that exchanging ideas can stimulate students' creativity. Nevertheless, she pointed out that discussion was not applicable to all English classrooms in China.

因为我觉得有些东西需要有一定的知识传输的。在他们那我看到的知识 传输的东西不多，就比如说我们讲，或者我们讲culture的东西，我觉得 culture这种东西你一定篇幅的lecture形式还是必要的，因为很多你要讲 了他们懂了才会有兴趣。而不是说你一个问题讨论我根本都没怎么学呢 , 怎么讨论。

\section{(Translation)}

I think that knowledge input is necessary for some courses in English class in China. In America, we noticed that there were little knowledge input in class. In China, we must introduce some cultural background in the form of lecture to provide the knowledge first, because students can only discuss something they understand and are interested. I cannot imagine how students discuss what they have no idea of.

Lily noticed that American students can unconsciously acquire cultural knowledge through life. In class, American teachers saved time in knowledge introduction and focused on encouraging students to expand from what they already knew. On the contrary, Chinese students still viewed classrooms as the sole place where they can get authentic language learning material. Hence, Chinese college English teachers still spend time in class to teach linguistic and cultural knowledge. My classroom observation confirmed what Lily stated. No matter what kind of courses the participants taught, lecturing was still the dominant teaching activity.

Another telling example of contextualization is importance of Chinese culture in participants' foreign language teaching classroom. All participants agreed that Chinese and Chinese culture were critical in English learning. Hence, they frequently compared American culture with Chinese culture. For instance, Haifeng 
taught students how to express starving to death, Americans say, "I can eat a horse", while Chinese preferred to say “我能吞掉一头牛” (I can eat an ox). She further explained that Chinese seldom say eat a horse because in the long history of China as an agricultural society, horses have played an important role as transportation vehicles.

Changing from a teacher to a guider or an instructor. Study abroad experience modified participants' perception of teacher's role from controller to instructor or guider. Furthermore, a teacher's role also decided the way to teach in classroom.

\section{其实真的我觉得短期访学对我的教学方法有蛮大的促进作用。因为前面 我讲过原先我对教师的理解也好，对教学方法的理解也好，这个层面还 是在teaching, 就是觉得我只要知识面比较宽, 我把我所有的知识告诉 给学生就可以了。但是通过这两次短期访学之后呢, 给我最大的一个触 动就是how to instruct students就是给学生要给予什么样的指导。他不是完全的一种灌输。}

\section{(Translation)}

I think short-term study-abroad programs promotes my teaching pedagogy. My previous understanding of being a teacher and perception of teaching pedagogy stressed the teaching aspect of being a teacher. I believed that as a teacher I just need to be knowledgeable and taught all what I knew to my students. But after study abroad twice, I learn how to instruct students, which is totally different from simple indoctrination.

Laura changed her view of being a teacher after observing the dynamic, communicative, and task-based American classroom. She was enlightened that it was unnecessary for teachers to be in charge of the whole class from the very beginning to the end; especially for the college student level. College English teachers were also responsible for guiding students in how to explore independently. Laura creatively instructed her students in class. In one of her classes, Laura divided her students in groups and asked them to answer questions on worksheet. These questions were open-ended because students cannot easily find answers from text and they needed to completely comprehend, summarize, contrast, and synthesize the reading material. I noticed that she circulated around and just provided help when students needed further explanation of the question or comprehension of the text. Later Laura participated in some group's discussion to scaffold students to think in depth. This sort of teacher-student interaction was more active and fruitful.

Being more reflective and critical in teaching. Study-abroad programs enriched the participants' experiences, broadened participants' horizons, and updated their ways of teaching. Haifeng summarized how study-abroad experience impacted her teaching as follows: 
至少我会经常想到我们学语言的要跟其他学科的教学不一样，就是要更 加自由一点...比方说选材，比方选听力材料，我干嘛一定要选教材上面 的呢? 我为什么不能直接到电台上面截一段给他们听呢?

...我现在就说对教材的挖掘更加深了吧，然后上课我也更认同那种，... 只要能够把这堂课上好，你采取什么方式都可以，不能太局限了。甚至 一个电影也行，我是这样想的，也就是说我更注重这种语言的本质，... 而不是去像原来一样要注重这种形式。...有一点我让学生做的更多的这 种research多了...但是我现在很多东西都是以那种task-based, research, group work, grouping然后针对某一个topic你们做summary啊，做一个comment啊， 我更注重这种互动，这种内容的互动，思想的互动。

\section{(Translation)}

At least I always reflect on how I should teach English in a more flexible way different from teaching other subjects... First of all, in terms of selecting teaching material, for instance I begin to ask myself why don't I directly choose excerpts from live broadcasting news...Second is interpretation of text. ...I think we should interpret the text in depth. Third is the teaching way. I agree that we should focus on the nature of language that is how to use language rather than the form of language. In order to achieve this purpose, we can try any way of teaching including watching a movie. Fourth is classroom activity. ...Now I group them to do more task-based research, summary, and comments. That is to say I pay more attention to interaction of minds.

Different from her previous routine teaching way, Haifeng reflected more on her own teaching. She began to have a critical attitude towards the textbook and was eager to find extra authentic teaching material for her students. She became more flexible in her teaching methods and more conscious in involving students in her classroom. Although she still explained or paraphrased texts for students, her focus shifted from the form of language to language use and her interpretation of text raised to a higher level of appreciation rather than simple understanding.

In sum, the influence of study-abroad experiences is pervasive in participants' teaching. They bring back advanced teaching methods, activities, techniques for classroom management, and ways to assess. They are willing to implement what they learned abroad into their own classroom with the hope of teaching reform for students' better academic achievement. They reach their goals because students have great interest in these stuff and trust them more than before. However, each coin has two sides. During integration, participants also encountered some obstacles due to 
issues related to students, physical environment, and administration. Despite these obstacles, participants teach in a more creative, reflective, and critical way.

\section{Discussions}

\subsection{Multiple and Confused Self-Perceptions}

Gee (2000) defined identity as "being recognized as a certain kind of person in a given context." In this sense, Gee connected identity construction with individual's social actions and interactions. That is to say everyone had multiple identities connected to their social performances. Gee's multiple faceted identity theory was echoed by Woodward (2002) who argued that as a function of the multiple and dynamic social worlds and social conversations that we participated in over time and space, each of us had a configuration of multiple identities forged in the dynamic interplay between discourse and practice, reification and participation, individual reflection and social recognition; indeed, identity arised out of this perpetual tension (p. 100). Similarly, many other researchers (Motha, 2006) also agreed that identity was multiple and ongoing.

Participants' perceptions of multiple struggling identities came from different social and cultural contexts. Based on my interviews and observation, participants dealt with conflict between being a Chinese and performing as an English teacher in their teaching in terms of role of Chinese and Chinese culture in English class. All participants allowed their students to use Chinese in the English classroom when students felt difficulty using English to express themselves. However, they did not achieve agreement in whether teachers should use Chinese as instructional language in English class. In the first interviews with each participant, Lily, Laura, and Jack pointed out that they just used Chinese to explain some abstract terms for the effectiveness of teaching and time saving. However, in classroom observations, Jack was the only participant who fluently used English to teach most of time with occasional Chinese translation of a word or phrase here and there. Lily used Chinese as the only instructional language. And Laura just used English and Chinese equally. In the second interview, Lily further explained her use of Chinese as that Chinese guaranteed the best learning outcomes because she could explain that it was more concise and more accurate for students to gain a better grasp of translation skills and techniques. Laura admitted that sometimes her language proficiency did not allow her to instruct fully in English. Lily, Laura, and Jack accepted the use of Chinese in the English classroom. In other words, they did not think that Chinese should be completely exclusive to English learning. However, Haifeng insisted that English teachers should use complete English to instruct. In my observation, Haifeng switched between Chinese and English more often than other participants and always had pause indicating her hesitation in pronunciation. She revealed that her choice of Chinese as an instructional language was not out of her willingness. Thus, she felt bad for using Chinese as an instructional language because her English proficiency was not good enough to sustain her complete use of English. Although participants differed in view towards Chinese use in English classrooms, they achieved in agreement that they felt more comfortable and confident in using Chinese. 
On the contrary, all participants set Chinese culture as an important element in their classroom teaching with following reasons. First, they thought that Chinese students should not get rid of Chinese culture. Second, they held the opinion that a solid foundation of Chinese culture could facilitate students' comprehension of American culture through comparison. Third, they believed that culture as a part of the liberal art was the core of being a human being.

Participants' different attitudes towards Chinese use and Chinese culture integration in English classroom indicated the dialogic relationship between language, culture, and identity. It also unveiled the conflicted self-identification of being a Chinese or an English teacher. On one hand, participants' personal identity of being English teacher and model for students' language learning was strengthened in the discourse of English classroom and through the interactions with their students. However, they had a huge burden of oral incompetence in fluent native-like English. On the other hand, their social identity of being Chinese was also activated when they were embedded with Chinese culture in China. They were proud of their mother language and home culture. Consequentially, pride and embarrassment, which stemmed from participants' social actions and interactions in different contexts, intertwined and coconstructed participants' multiple and conflicted identity.

\subsection{Changing Perceptions of Eligible and Competent English Teacher}

Based on activity theory, identity is a kind of mediated activity and identity construction is a dynamic process of becoming through activity within the social, cultural, and historical context. In the same vein, Gee (2000) articulated that people had specific experiences within specific discourses. This trajectory and people's own negotiation and meaning making of it constitute their identity that is never fully formed or always potentially changing.

Study-abroad experiences also shaped participants' understanding of being a competent English teacher. Participants listed their previous criteria for eligible and competent English teachers as standard pronunciation, sharp linguistic skills, solid grammar knowledge, and abundant cultural knowledge. Among these, they ranked pronunciation and linguistic skills on the top of list. After they came back from abroad, they shifted their perception of eligible and competent English teacher into focus on language use, sense of culture, diversified teaching pedagogy, ability in raising students' interest in independent exploring, and teachers' charm. The most obvious difference was that they never evaluated linguistic skills and pronunciation as the only criteria for English teacher. Laura explained her understanding of charm as the teachers' specialty. Simply speaking, charm indicated a teacher's strength. Laura stated that teachers could make use of their strength to organize and to design classroom activities to encourage students to learn. For instance, if the teacher has a wide range of knowledge, he/she can design various projects for students to explore by themselves; in this way, the teacher can make use of his/her rich knowledge as supplementary teaching material to help students learn.

In the current study, participants' changing perceptions of eligible and competent English teacher was due to changed academic and social contexts. As neophytes in 
American classrooms and society, participants encountered various new aspects of teaching that were totally different from their routine classroom instructions. Their negotiation of being a competent and eligible English teacher was not only related to individual but also to collectivity. In addition, their changing understandings reflected dynamic evolution of identity.

\section{Conclusions}

This study was designed to explore how Chinese in-service college English teachers constructed and changed their teacher identity through their study-abroad experiences. The participants in the present study were asked to describe their study-abroad experiences, compare their perceptions of a legitimate English teacher before and after study-abroad, and share their teaching experiences after coming back. In general, findings showed that Chinese college English teacher identities constructed and reproduced as they gained new knowledge and experiences during the study-abroad program. What is more, the study focused on discourses of study abroad experiences and teaching practices in China; specific implications were directed to stakeholders such as college English teachers, administrators and foreign directors of study-abroad programs. As educational exchange and cooperation become more and more welcomed and popular around the world, it becomes increasingly crucial for English teachers, administrators, and directors of studyabroad programs to reflect on how to make study-abroad programs fundamentally effective to in-service teachers' professional development that will lead to students' greater academic achievement.

\section{References}

Ajayi, L. (2011). How ESL teachers' sociocultural identities mediate their teacher role identities in a diverse urban school setting. The Urban Review, 43(5), 654680.

Akkerman, S. F., \& Meijer, P. C. (2011). A dialogical approach to conceptualizing teacher identity. Teaching and Teacher Education, 27(2), 308-319.

Allen, H. W. (2010). Language- learning motivation during short- term study abroad: An activity theory perspective. Foreign Language Annals, 43(1), 2749.

Allen, L. Q. (2010). The impact of study abroad on the professional lives of world language teachers. Foreign Language Annals, 43(1), 93-104.

Barhuizen, G., \& Feryok, A. (2006). Pre- service teachers' perceptions of a short- term international experience programme. Asia-Pacific Journal of Teacher Education, 34(1), 115-134.

Barnawi, O. Z., \& Le Ha, P. (2015). From western TESOL classrooms to home practice: a case study with two 'privileged' Saudi teachers. Critical Studies in Education, 56(2), 259-276. 
Beijaard, D., Meijer, P. C., \& Verloop, N. (2004). Reconsidering research on teachers' professional identity. Teaching and Teacher Education, 20(2), 107128.

Britzman, D. (2003). Practice makes practice: A critical study of learning to teach (Revised ed.). Albany, NY: State University of New York Press.

Darling-Hammond, L. (2000). How teacher education matters. Journal of Teacher Education, 51, 166-174.

Duff, P.A., \& Uchida, Y. (1997). The negotiation of teachers' sociocultural identities and practices in postsecondary EFL classrooms. TESOL Quarterly, 31, 451-486.

Gee, J. P. (2000). Identity as an analytic lens for research in education. Review of research in education, 25, 99-125.

Gleeson, M., \& Tait, C. (2012). Teachers as sojourners: Transitory communities in short study-abroad programmes. Teaching and Teacher Education, 28(8), 1144-1151.

Golombek, P., \& Jordan, S. R. (2005). Becoming "black lambs" not "parrots": A poststructuralist orientation to intelligibility and identity. TESOL Quarterly, 39(3), 513-533.

Institute of International Education. (2008). Open doors: Report on international educational exchange. Retrieved November 17, 2008, from http://opendoors.iienetwork.org/

Institute of International Education. (2015). Open Doors Report on International Educational Exchange. Retrieved from http://www.iie.org/Who-We-Are/News-andEvents/Press-Center/Press-Releases/2015/2015-11-16-Open-Doors-Data\#.V78EZCgrK70

International Office. (2013, April 2). Guоjihua banxue diaoyanbaogao [A survey report on internationalization of education]. International Office of Shandong University of Finance and Economics. Retrieved from http://international.sdufe.edu.cn/info/1021/1124.htm

Johnson, K. (2001). Social identities and the NNES MA TESOL student. Retrieved from http://files.eric.ed.gov/fulltext/ED457682.pdf

Lavender, S. (2002). Towards a framework for language improvement within short in-service teacher development programmes. In H. Trappes-Lomaz \& G.Ferguson (Eds.), Language in language teacher education (pp. 237-250). Amsterdam: John Benjamins.

Lee, I. (2013). Becoming a writing teacher: Using "identity" as an analytic lens to understand EFL writing teachers' development. Journal of Second Language Writing, 22(3), 330-345.

Lee, J. F. (2009). ESL student teachers' perceptions of a short-term overseas immersion programme. Teaching and Teacher Education, 25(8), 1095-1104.

Mantero, M. (2004). Transcending tradition: Situated activity, discourse, and identity in language teacher education. Critical Inquiry in Language Studies, $1,143-161$.

Martel, J., \& Wang, F. (2015). Language teacher identity. In M. Bigelow \& J. Ennser-Kananen (Ed.), The Routledge handbook of educational linguistics (pp. 289-300). New York, NY: Routledge. 
Zhao \& Mantero, The Influence of Study-Abroad Experiences on Chinese College EFL

Martel, J. (2015). Learning to teach a foreign language: Identity negotiation and conceptualizations of pedagogical progress. Foreign Language Annals, 48(3), 394-412.

Merrell, F. (2003). The Mexicans: A sense of culture. Boulder.

Ministry of Education. (1993, Febrary 13). Jiaoyu gaige he fazhan gangyao [Outline for Education Reform and Development in China]. Ministry of Education of People's Republic of China. Retrieved from http://www.edu.cn/zong_he_870/20100719/t20100719_497964.shtml

Ministry of Education. (2004, Febrary, 10). Jiaoyu zhenxing xingdong jihua [20032007 New Action Plan to Revitalize Education]. Ministry of Education of People's Republic of China. Retrieved from http://www.moe.edu.cn/publicfiles/business/htmlfiles/moe/moe_177/200407/2 488.html

Ministry of Education (2007, November 26). 2008 niandu xinjiapo nanyangligong daxue gaoxiao yingyu jiaoshi jinxiu xiangmu linxuan tongzhi [Ways to select English teachers in higher education institution for Singapore NTU English Teachers' Training Programme in 2008]. Ministry of Education of People's Republic of China. from http://v.csc.edu.cn/Chuguo/aefa49418afd4b5aa76eff242af351d9.shtml

Ministry of Education (2011, November 22). 2012 nian gaoxiao yingyu jiaoshi chuguo yanxiu xiangmu [Reports on study-abroad programs for English teachers in higher education institutions in 2012]. Ministry of Education of People's Republic of China. Retrieved from http://v.csc.edu.cn/Chuguo/c7959b7b8db44fb0b1c6ca370add01ff.shtml

Morgan, B. (2004). Teacher identity as pedagogy: Towards a field-internal conceptualisation in bilingual and second language education. International Journal of Bilingual Education and Bilingualism, 7(2-3), 172-188.

Morgan, B., \& Clarke, M. (2011). Identity in second language teaching and learning. In Eli Hinkel (Ed.), Handbook of research in second language teaching and learning, Vol. 2 (pp. 817-836). New York, NY: Cambridge University Press.

Motha, S. (2006). Racializing ESOL teacher identities in US K- 12 public schools. TESOL Quarterly, 40(3), 495-518.

Stake, R.E. (1998). Case studies. In N.K. Denzin \& Y.S. Lincoln, (Eds.), Strategies of qualitative inquiry (pp. 86-109). Thousand Oaks, CA: Sage Publications.

Stake, R.E. (2005). Qualitative case studies. In N.K. Denzin \& Y.S. Lincoln, (Eds.), The sage handbook of qualitative research (3rd ed.) (pp. 443-466). Thousand Oaks, CA: Sage Publications.

The Central People's Government (2007, March 26). Guyu wanshan zhicheng waiyu kaoshi youguan wenti de tongzhi [Notification on issues of foreign language examination for national professional and technical personnel]. The Central People's Government of the People's Republic of China. Retrieved from http://www.gov.cn/zwgk/2007-03/26/content_560871.htm

Thompson, G. (2002). Teachers studying abroad: An analysis of changes in linguistic and cultural knowledge and attitudes toward the spanish culture and 
Zhao \& Mantero, The Influence of Study-Abroad Experiences on Chinese College EFL

the effects of ethnographic interviews. Paper presented at the 2002 TEXFLEC Conference.

Trent, J. (2011). Learning, teaching, and constructing identities: ESL pre-service teacher experiences during a short-term international experience programme. Asia Pacific Journal of Education, 31(2), 177-194.

Varghese, M. (2000). Bilingual teachers-in-the-making: Advocates, classroom teachers, and transients. Unpublished doctoral dissertation, University of Pennsylvania, Philadelphia.

Varghese, M. (2001). Professional development as a site for the conceptualisation and negotiation of bilingual teacher identities. In B. Johnston and S. Irujo (Eds.), Research and Practice in Language Teacher Education: Voices from the field (pp. 213-232). Minneapolis, MN: University of Minnesota, Centre for Advanced Research in Second Language Acquisition.

Varghese, M., Morgan, B., Johnston, B., \& Johnson, K. A. (2005). Theorizing language teacher identity: Three perspectives and beyond. Journal of Language, Identity, and Education, 4(1), 21-44.

Wang, D. (2014). Effects of study abroad on teachers' self-perceptions: A study of Chinese EFL teachers. Journal of Language Teaching and Research, 5(1), 7079.

Woodward, K. (2002) Understanding identity. London: Arnold.

Yazan, B. (2014). How ESOL teacher candidates construct their teacher identities: A case study of an MATESOL program. Retrieved from http://drum.lib.umd.edu/handle/1903/15789

Yin, R.K. (2009). Case study research: Design and methods (4th ed.). Thousand Oaks, CA: Sage Publications. 